\title{
Journalists and Sociologists
}

Reviewing the Battles over Ways of "Giving an Account of Society"

Vincent Goulet and Philippe Ponet

Translator. Inist

\section{(2) OpenEdition}

\section{Journals}

Electronic version

URL: http://journals.openedition.org/questionsdecommunication/8882

DOI: 10.4000/questionsdecommunication.8882

ISSN: 2259-8901

\section{Publisher}

Presses universitaires de Lorraine

\section{Printed version}

Date of publication: 1 December 2009

ISBN: 978-2-8143-0003-3

ISSN: 1633-5961

\section{Electronic reference}

Vincent Goulet and Philippe Ponet, « Journalists and Sociologists », Questions de communication

[Online], 16 | 2009, Online since 01 February 2014, connection on 19 April 2019. URL : http:// journals.openedition.org/questionsdecommunication/8882 ; DOI : 10.4000/

questionsdecommunication.8882

This text was automatically generated on 19 April 2019

Tous droits réservés 


\title{
Journalists and Sociologists
}

Reviewing the Battles over Ways of "Giving an Account of Society"

\author{
Vincent Goulet and Philippe Ponet
}

Translation : Inist

\section{EDITOR'S NOTE}

This English translation has not been published in printed form/Cette traduction anglaise n'a pas été publiée sous forme imprimée.

1 A complex landscape of interdependent connections, a tangled web of motivations and interpenetrating methods and tools: such is the picture that emerges from the few existing studies on relationships between journalism and sociology. Recurrent themes include a somewhat indistinct "dividing line" (Ruellan, 1992 : 25), "lines of demarcation between the two camps", "zones of contact", "ring-fencing / étanchéité" (ibid.), and the various "affinities and misunderstandings" that result (Charon, 1996:17). Other topics discussed are methods and tools (press cuttings, interviews), with analyses of "borrowings, legitimate or not" (ibid. 30) between journalists and sociologists, conflicts of legitimacy and different ways of treating "actual facts".

While this literature usefully underlines the particularities of the two disciplines, it sometimes tends to reinforce, or even to naturalize, certain areas of opposition journalists and sociologists are taken for granted as having always belonged to clearly distinct spheres - and to impose ways of constructing the object by merely considering as a "problem" between journalists and sociologists something that actually reflects much more far-reaching transformations of society ${ }^{1}$, and in particular the question of intensifying conflict, from the second half of the 19th century, between the different activities that claim to "give an account of society" ("crier le social") ${ }^{2}$. This is why any attempt to classify this literature, which works on the assumption of "journalism" and "sociology" as opposed spheres and delves no further than the most obvious polemics between them, is likely to obscure the real affinities between journalists who try to raise 
their "level of professional autonomy" by drawing on the social sciences, and sociologists who, in the name of science, try to "shed light on" journalistic practice ${ }^{3}$. Despite the rather tough debates between two seemingly irreconcilable positions ${ }^{4}$ (with scientific authors wanting to see more reflexivity in journalistic practice and journalists raising the symmetrical question of introducing journalistic schemes of perception into the academic field ${ }^{5}$ ), they converge in terms of their normative tendency and in their eminently political conception of the nature and functions of the news media. Alongside these two apparently antagonistic approaches can be discerned somewhat more nuanced approaches among those whose position is half-way between journalism and the humanities, such as former journalists who have become academics, academics who have switched to journalism or journalists with high-level qualifications in the humanities ${ }^{6}$.

Thus, although their many contributions are not in doubt, these studies seem to have focused on conflicts between journalists and sociologists rather than taking them as an object of study. One of the aims of the seminar organized in June 2006 at the School of Higher Studies in the Social Sciences (EHESS), and which paved the way for this publication $^{7}$, was to contribute to further analysis of these questions without, as far as possible, falling into either rival camp. The contributions to the seminar brought the analysis of relationships between journalists and sociologists into the wider field of social mechanisms. Two of these contributions are highlighted in particular : the intensifying battles over "giving accounts of society" since the second half of the 19th century in a field that was beginning to split into two and the increasingly frequent reciprocal uses of journalism and sociology, with the latter's establishment as a discipline in its own right in the first half of the 20th century as the necessary condition for the two to interact.

\section{The growing weight of words: mixing genres and diversifying ways of "giving accounts of society"}

The changing trends in relationships between journalists and sociologists are, obviously, closely tied to an intensification of symbolic conflicts in human activities. The importance of journalistic and sociological practice in most Western societies is partly the result of the process of civilization, as described by Norbert Elias who showed how, with the gradual retreat of physical violence and the advent of individual control over impulses and emotions, humans gradually acquired rationalized knowledge about their actions and thus contributed to the emergence of multiple kinds of discourse on their own practices ${ }^{8}$. In this sense, the history of relationships between journalists and sociologists can be seen as a sign of intensifying conflict waged not through warfare but through words. The tension in the first few lines of Balzac's monograph on the Parisian press $(1843: 62)$ is revealing in this respect: "France has two faces. Eminently military in wartime, she also exerts poser in peacetime through her ideas. The sword and the pen, these are her weapons of choice [Translator's note: This is my own translation]". This is in fact why the relationships that have been forged between these two spheres cannot be understood without referring to the emergence of and gradual achievement of autonomy in other spheres at the same time - such as politics and literature (Bourdieu, 1998 ; Offerlé, 1999; Phélippeau, 2002 ; Lettieri, Saitta, 2006) - that aimed to show the meaning of human activities by putting them into words and without accounting for them in terms of the social division of labour that had become increasingly marked since the late 19th century. Understanding how the links between these two areas have changed then requires a 
historical perspective, if only to avoid the various pitfalls of using a constant assumption whereby journalism and sociology tend to be analysed through patterns of perception and classification that have only been valid since these two spheres became relatively autonomous. Put more simply, while it seems "obvious" and "legitimate" nowadays to question the mechanisms of competition and/or collaboration between journalists and sociologists, this has little relevance to the 19th century as the two spheres were not yet established in their own right. What is observed is rather a mixture of genres, the relatively indeterminate positions - of "journalists" or "sociologists", but also of "politicians" or "literary figures" - and uses of survey techniques that were not mutually exclusive.

5 As we know, early works on the working classes combined different methods of "observation" and, often, a moral tone, recommendations on hygiene and political denunciations, or were published as literary narratives. To cite some of the best known among very many possible examples, Friedrich Engels, in writing his "Condition of the Working Class in England" in 1845, used his own observations, the accounts of his partner (an Irish working class woman) and his readings of two working class newspapers published in Manchester, the Northern Star and the Manchester Guardian. In 1855, the monographs on the working class of Frédéric Le Play, a progressive and paternalistic Catholic, drew on the native expertise of "key informants" (priests, doctors, schoolteachers living in working class neighbourhoods) and analyses of family budgets. He was able to do this because his training as a mining engineer enabled him to "observe" workers' living conditions over a long period, but also because his professional journeys and his training in the "natural sciences" gave him the foundations to invent scientific schemes for social analysis (Arnault, 1984). We know that Émile Zola used to take a great many "ethnographic" notes before he began to write a novel. His observations of the Anzin mines were also decisive to the writing of Germinal'. As shown in Vincent Goulet's contribution, the study of Dick May's social and professional trajectory and his attempt to set up a course in journalism at his school of higher social studies illustrate the lack of a well defined identity at this time: the question of teaching reveals the competition between different conceptions of the two disciplines and the political battles around them. More generally, the mixture of genres can be seen in one of the branches of publishing - "studies of social mores" or "panoramic literature" - where the sole aim is to relate the life of society through narratives, novels, essays and moral and political reflections, which together form a whole that may seem disparate today but at the time made up a large part of "scholarly" or "semi-scholarly" publications ${ }^{10}$.

6 In fact, it was only by making concessions to the history of the discipline and to the necessarily retrospective writing involved that these "founding fathers" could be credited with strategic intentions to achieve the disciplinary autonomy that matches what these disciplines later became ${ }^{11}$. Bernard Lacroix (1981) showed that Emile Durkheim's attentiveness to the political issues of his time was masked for a long time by his work on the foundations of sociology as a science. In some of the texts he published in "sociological" or "philosophical" journals can be discerned a rhetoric in which sociology is used to disqualify what he considers to be "scientific heresies" or to assert the permanence of certain traits he considers as anthropological constants (Durkheim, 1899). A comparative review, from this angle, of the history of the social sciences and journalism brings out the many points of contact that have appeared between the two disciplines, for example in the works of Sandrine Lévêque (2000) on social reporting, in the contributions 
of Robert E. Park, who moved from journalism to the Chicago "school" of sociology (Bourmeau, 1988; Chapoulie, 2001: 91-103; Park, 2008), or in American "precision journalism" or Susan Allen's "media anthropology" (Coman, 2003: 6-7) in the 1960s, which attempted to import social science techniques into journalistic practice. Another example where the two approaches clearly intermingle is the "new journalism" that advocates a subjective view of reality in the name of the "authenticity of experience" and its power of social mobilization. Up to a point, the extreme left-wing militancy of the early Libération newspaper, where the idea was to give a voice to the people through individual accounts or by placing an emphasis on columns considered to be devoid of political interest, such as small ads or "trivial" news items, is an example of the words of ordinary people becoming objects of sociological study ${ }^{12}$. As we see, the history of relationships between journalists and sociologists, like that of specialization processes, is the history of the indeterminacy of genres or, to be more precise, of the continual reconstruction of legitimate genres, whatever the scope actually left for approaches that closely combine ethnological surveys, statistics, literary accounts or political, moral or religious standpoints. While studies of past or contemporary relationships between sociology and journalism should not take sides in attempts to establish the autonomy of the two groups, they should nevertheless acknowledge the importance of their claims to "autonomy", which is clearly one of the prerequisites for legitimate "accounts" of society.

\section{The emergence of "autonomy" and its multiple uses: the changing balance of power between sociology and journalism.}

Reconstructing the genesis, and especially the uses by journalists and sociologists of their "professional autonomy", bring out their respective "powers" wielded not so much through the resources available to them but through changes in patterns of domination and in the logic underlying the conversion of their specific capital in the social sphere. Although they do not always account for the multiple kinds of logic underlying the autonomization and professionalization of a discipline ${ }^{13}$, historical studies on the gradual construction of each group have two advantages. By describing the stages through which the distinctive "attributes" of a profession are gradually obtained ${ }^{14}$, in the context of what Terry Shinn has called the "disciplinary regime" 15 , these studies first of all give a good idea of the dissimilarities and areas of opposition that became established between the two groups and made them mutually irreducible. They thus bring out the differences not only in terms of professionalization ${ }^{16}$, but also in their relationships with other social spheres. By showing the different tensions that affect each group, they point out that referring to "journalists" or "sociologists" is merely a convenient discursive short-cut for designating these groups, which are themselves affected by the continuing process of the social division of labour ${ }^{17}$. Talking about the relationships between "journalists" and "sociologists" is meaningless unless the properties of the journalists and sociologists in question are specified : are they research staff, research directors at the CNRS, university lecturers or professors, temporary staff or sociology PhDs without a post? Have they written peer-reviewed articles or books? Do they occupy a position in a learned society or a university ${ }^{18}$ ? Are they freelance journalists, salaried journalists or editors in chief? Do they work for the written press, radio or television? Did they attend a school of journalism or a political sciences institute, or did they learn their trade "on the job" ? Do 
they write for a national daily, a weekly or a specialized monthly? Given the many possible distinguishing criteria, we need to look beyond the simple division between professional groups and offer the hypothesis that the structure of their relationships has evolved in accordance with more general social processes, principles of elective affinity and mechanisms of structural homology ${ }^{19}$.

9 From this angle, the few analyses that attempt to account for these processes of professionalization and autonomization through the lens of the conflicts they engender between different social groups are the most interesting. For example, Patrick Champagne (1995) pointed out the "double dependency" of the journalistic field on the logic of politics and economics. More recently, and explicitly in line with these programmatic orientations, Ivan Chupin and Jérémie Nollet (2006: 15-36) have underlined the potential value of a "historical sociology of the interdependence of journalism and other social spheres". Setting out the main lines of this idea, they show that a shift occurred from journalism through "horizontal" networks in the late 19th century to the 1920s and 30s to journalism practiced under political constraints and then under growing economic pressure from the 1970s. Finally, they observe that the "power" attributed to journalists nowadays is above all a "structural" form of power deriving from their focal position in current affairs. To be more precise, some will tend to attribute "power" to the media because of beliefs they may invest in them that stem from the situation of interdependence between journalists and social players (ibid. : 31$)^{20}$. From this point of view, analysing the relationships between journalists and sociologists necessarily requires consideration for the shifting balance of power between them. While it seems that for a long time, "intellectuals" exercised a kind of ascendancy over journalists by imposing and controlling the dissemination of their schemes of perception of the social sphere, the balance of power seems to have been reversed in the last few decades, so that we are now seeing a "destabilization of the discursive registers" of intellectuals, but also of politicians. Bastien François and Érik Neveu comment that "recent decades have seen spectacular redefinitions of intellectual hierarchies and inflicted various narcissistic wounds on the intellectuals most closely tied to educational and academic institutions and to the most legitimate sectors of cultural production and dissemination. [...] More recently, the rise of journalistic power and the use of media visibility as a way of shortcircuiting internal legitimation procedures in the intellectual field have reinforced a tendency among intellectuals to reject a shift in which they see an imminent threat of being toppled from their last bastions of power in society" (François, Neveu, 1999: 17-18). Further on, they discuss the "dénouement of a tremendous battle to define the symbolic hierarchy of titles in saying what is to be said, a battle clearly won by the journalistic camp, which awarded itself jurisdictional authority over the intellectual world" (ibid.: 38).

10 While the growing ascendancy of journalism over other social spheres (Bourdieu, 1994) seems clear, it still needs to be specified. The current configuration in which journalists and sociologists operate (and also politicians, economists and others) can only be really understood in the light of both the comparative historical conditions of production in the two spheres and the accentuating social division of labour. It is as if the increasing complexity of human societies had not affected the organization of sociology and journalism in the same way, in particular because of their very different historical attachment to autonomy. The relative success of Durkheim's "strategy"21 to found sociology as an autonomous profession via the academic world has contributed directly to 
the declining power of sociological discourse in the social sphere. As Vincent Goulet's contribution shows, it seems that a different conception of the social sciences succeeded in gaining ascendancy in the early 20th century, that of Dick May for example, which was far more sensitive to its dissemination among social groups, including the least dominant, in particular through their "leaders of opinion" or supervisory staff (teachers, union leaders, etc.). The success of Durkheim's enterprise has resulted in a sociology founded on the model of the natural sciences and tending to hold institutional, but also scientific, autonomy in particularly high esteem. The analysis by Dominique Merllié (2004) of the refusal of a majority of the Durkheim "school" to follow the "intellectual fashion" for surveys reflects, to some extent, this tendency towards isolationism. In the spirit of Émile Durkheim, "good" sociology cannot be assimilated with the "social question" and with "socio-political aims" (ibid. : 150 et sq.). In line with this idea and in the same way as the "hard" sciences, sociology thus developed during the 20th century by continually extending its fields of specialization. The result today is a very evident segmentation of its fields of analysis and relatively little in the way of exchanges between these different segments ${ }^{22}$. For sociology to be an active component of society, it now has to act through other sectors, including journalism, as shown here in the contribution from Julie Sedel on two sociologists specialising in questions of delinquency and "insecurity", and from Aurélie Tavernier on how sociologists get access to the media in practice.

11 A contrario, on the journalism side, "good" journalism was defined for a long time by "on the job" apprenticeship, the ability to adopt a general perspective on the world and a rejection of narrow specialization. Illustrating this is the relative "failure" of the first school of journalism created by Dick May 1899 and the fact that the French Higher School of Journalism (ESJ) was created in 1924, for reasons more ideological than professional, by Catholics with a concern to counteract the leftist cartel. The Journalism Training Centre ( CFJ) was only founded in 1946 with a view to the reconstruction of France's national identity. It was not until the 1960s that the idea emerged of offering true public vocational training for journalists, through the creation of the Centre universitaire d'enseignement du journalisme (CUEJ) in 1958, the CELSA in 1965 and the IUT in Bordeaux in 1967. While today, in theory, schools of journalism recognized by the profession do not have a monopoly over training, they are increasingly an almost mandatory step towards employment in the dominant field, i.e. the audiovisual media, the AFP and the national dailies $^{23}$. While this "professionalization", which occurred at a later stage for journalism, was in line with the general trend towards qualifications as a prerequisite to enter the labour market, it nevertheless maintained a non-specialist character; as noted by Dominique Marchetti (1997 : 170-255 ; 2002), "the higher their rank in the hierarchy, the more "generalist" journalists tend to be". Thus, despite the emergence of different "thematic" categories in the written press, the circulation of "issues" and reflections is much more fluid in the media than in the sphere of sociology ${ }^{24}$ : depending on the issues of the day and the current balance of power, a question may be treated under different headings in turn (Marchetti, 2006).

12 From the relational point of view, then, the question of autonomy arises in very different terms for journalists and sociologists: to a journalist, autonomy means defending "freedom of the press", which in effect means denouncing the least euphemistic forms of pressure (often from political authorities and more rarely from economic constraints) ${ }^{25}$, but it does not mean rejecting all relationships with other social spheres. It would even be true to say that journalism only exists because it is capable of handling, within the same 
sphere of visibility, the trains of thought of many different players involved in different activities in the social sphere (Ponet, 2007). Conversely, the use of reflexivity, prized by sociologists, is up to a point the logical conclusion of the drive towards autonomy : only sociologists, with the aid of the tools they have developed, can attempt to revisit their own practices. In this sense, rather than discussing different degrees of autonomy, it would be more relevant to discuss the different forms and uses it has developed in different areas and at different times. It then becomes possible to reinterpret the "decline" of the academic intellectual, and thus of sociologists ${ }^{26}$, in comparison with journalists, as the result of the very different "management" of the ongoing social division of labour and the lengthening chain of interdependence. Finally, it is the component attributed to autonomy in the definition of group identity that seems to account for the current reversal of the balance of power between the two disciplines. To summarize, while in the past, a stance could be taken up in the social sphere on the strength of the conversion, at the end of a career, of specific knowledge capitalized over a long period - especially via the media (which accounts for the fact that only the most well-established voices could be heard), since the 1980s and 1990s and the liberalization of the audiovisual media, it seems that those who succeed in making their mark on the "public sphere" are individuals with multiple positions who accumulate different forms of capital simultaneously in different fields and who, especially, are able to handle the different kinds of underlying logic together ${ }^{27}$. It seems, then, that the principles on which sociologists operate prevent them from becoming involved in these new patterns in the balance of power ${ }^{28}$ : there has been a shift from the power that stemmed primarily from the capacity for using specific positions of authority in other fields to a more diffuse kind of power that lies in the capacity for coordinating different kinds of logic ${ }^{29}$. The best way of assessing these transformations is therefore to investigate the reciprocal uses by journalists and sociologists of their respective disciplines and how they mutually benefit from doing so.

\section{Some reciprocal uses of sociology and journalism}

While this two-part presentation primarily obeys scholastic logic - since "borrowings" are always joint and reciprocal - it helps to clarify the matter at hand by making a distinction between the analysis of media uses of sociology and that of sociological uses of the media. There is no doubt that studies on the uses of expert discourse in the written press, including by sociologists, have generated the most numerous analyses. Drawing on her work on this question, Aurélie Tavernier (2004) shows how the discourse of sociologists is a resource for journalistic rhetoric in the construction of daily news items. With the help of figures, she analyses the forms taken by "reported speech" in sociology quotations, interviews, discussion forums, etc. - and shows what they owe to the writing "strategies" of journalists, such as the use of an analytical-descriptive register to reinforce a point of view, the authoritative voice of an expert or having opinions voiced in context. In her study of the various negotiations around the "licence to speak" and the power relationships that stem from this, the author highlights some of the ways in which the media represent "good sociology". Finally, a picture emerges of the processes governing the legitimation of speech and the tensions between journalists and sociologists that can result. 
Ivan Chupin points out another use of the social sciences by journalists. He shows how schools of journalism, in their efforts towards replication, try to capture the symbolic capital of the social sciences to answer recent criticisms about focusing too narrowly on the "operational" and to strengthen their competitive position in relation to sociology. Many of her remarks shed light on the history of the division of labour between universities and professional sectors in the socialization and professionalization of young journalists (Neveu, 2006). The question of certain sociologists' involvement in schools of journalism raises the more general question of the dissemination of humanities tools and methods among journalists (and more broadly within the social sphere), whether through university training for journalists, who often take courses in sociology if not a full degree curriculum, or through the naturalization of certain survey methods used by journalists (opinion polls, interviews and sometimes observation).

The question of methods is central to Julie Sedel's contribution, which shows, through two high-profile sociologists, how different conceptions of social science have clashed as they moved out of the scientific sphere to compete in the media. This study explicitly raises the question of the "political" retranslation ${ }^{30}$ of certain sociological works for a wider audience, whether by the media themselves or through the position of a political expert. This brings in the principles of structural homology and elective affinities mentioned above, which can, in some cases, bring sociologists, journalists and politicians together around common "issues". This example also points to the relative lack of success of sociological discourse in gaining legitimacy outside the academic sphere as a way of giving an account of society : in comparison with other fields of the humanities, and especially given the predominance of psychological and economic schemes of thought (as illustrated by the many "general readership" monthlies specialising in these fields (Duval, 2004) and, more specifically, the ever-increasing number of "psychology" or "economics" sections featured in many publications), it has to be recognized that the penetration of sociological discourse (mainly through statistical data) is far more diffuse. What still needs to be understood in more depth are the reasons for these different degrees of "success".

While these examples illustrate some of the possible uses of sociology in journalism, they also, conversely and in different ways, raise the question of uses of the media in sociology. The contributions from Aurélie Tavernier and Julie Sedel detail the social properties of sociologists who appear in the media and help to understand the interests they may have in a wider dissemination of their discourse. Similarly, Ivan Chupin's analysis clearly shows how strengthening the social sciences in schools of journalism enables some academics, including sociologists, to assert their institutional position not only in the academic world but also, in some cases, by providing expert advice to ministries, or to widen their networks of informants (former students working in journalism) $)^{31}$. Although uses of the media in sociology are inextricable from uses of sociology by the media, and have already been the subject of several studies, we felt that some of these were not sufficiently investigated in depth. This is the case, in particular, of the uses made by humanities researchers of the vast corpus of material offered by the written press, radio and television ${ }^{32}$.

Two kinds of discrepancies reveal this lack of interest. The first is the discrepancy between the increasing number of works describing different survey techniques, sources used by the humanities and the virtual non-existence of specific studies on the possible uses of journalistic sources ${ }^{33}$, which are often presented as one written source among 
many. Correlatively, the second discrepancy is between the results of sociological analyses of journalism and their low level of dissemination in other fields of the humanities. While many studies set out to describe the complex structure of the media sphere and continually stress the increasing number and specialization of press titles, despite studies that have emerged in recent years on different types of specialized press titles, involvement from scientists is still mainly concentrated in the national daily papers even though these are a minuscule part of the media landscape in France (Marchetti, 2002). While there is no doubt a kind of "dominocentrism" ${ }^{34}$ among academics and scientists that encourages this "Jacobin" interpretation of media coverage ${ }^{35}$, how a press corpus is constituted in practice (use of indexing in some cases ${ }^{36}$, time available for collating data, etc.) is still awaiting investigation. The selection of sources seems closely linked to their degree of legitimacy, in other words their proximity to the objects that are most representative of the academic sphere.

More generally, the question of scientific selection in the media needs to be linked to the question of media selectivity. We know that, depending on the media chosen as a source of information, the connections that ultimately emerge can be very different. Therefore, selecting certain national dailies "naturally" or "spontaneously" is not neutral. In this sense, a reflexive view of scientific selection in the media can help to further investigations into certain mechanisms that censor scientific work, for example why certain objects are taken for granted as worthy of interest, which sometimes reinforce the censorship occurring in the field of journalism itself (for example, issues reported in the least legitimate media are often far-removed from those featured in the national daily press (Champagne, Marchetti, 2002).

To continue these investigations into the reciprocal uses of sociology and journalism, there is a need, finally, for more systematic comparisons of the instruments used in each discipline - interviews, observations, use of statistical sources, surveys based on questionnaires (opinion polls), uses of "ordinary" people's words, portraits, etc. - and especially, of their uses for specific purposes that nevertheless allow claims, in each case, to a form of "objectivity".

While journalists and sociologists have a great many tools in common for investigating reality, are there grounds for assertions, such as those of Robert E. Park in his time, that a sociologist is a kind of super-reporter with more time and more means to conduct enquiries? Gérard Mauger has underlined the kinships between the worlds of journalism and sociology and the way professional excellence on the one side borrows from the way it is defined on the other side (Mauger, in: Sedel, 2009:9-12). He suggests that the main difference in the conduct of enquiries lies in the use of multiple sources by sociologists and the use of preferred sources by journalists, which in effect has to do with the amount of time devoted to the enquiry. Another important difference is that reflexive practice, in other words scientific control of the enquiry process and the position of the enquirer within it, is much more elaborate in sociology than in journalism.

21 The text by Elihu Katz - "Journalists as scientists", translated here into French - outlines avenues for in-depth reflection on the question of methodological kinship between journalism and sociology. By drawing a comparison between journalism and other professional spheres, especially the liberal and scientific professions, Elihu Katz underlines the lack of definition and the contradictory demands of journalists' activities. He stresses the journalist's conception of "public service" and "serving the public" while noting the absence of any corpus of sound knowledge and methods they can rely on. 
Adopting a constructivist point of view, he suggests that journalists "manufacture" social representations by taking on board accepted standards in the society in which they work. Elihu Katz's notes gradually outline the contours of a native journalistic theory which is distinct - despite what he seems to say himself - from the scientific conception: a voluntarist conception of action that gives primacy to "great men" and to irruptive events, a hierarchical organization of facts according to their capacity for being kept on the public agenda (which converges with Parks' ideas on human interest) and involvement in the dynamics of social conflict in terms of "crisis" mapping and practical resolution. These fundamental traits of journalistic practice radically separate them from the scientific activity of sociologists, whose overriding concern is to understand, from a distance, the objective transformations of social structures. Discussing the positions of Edward Jay Epstein on the "essential incompatibility of journalism and truth", Elihu Katz, finally, adheres to the cultural conception of journalism outlined by John Dewey in the 1920 s as a reaction to the demands of Walter Lippmann ${ }^{37}$. The differences between journalists and sociologists lie not so much in their methods and/or tools of investigation as in the uses they make of them, and especially in the ultimate purpose of their output. To summarize, journalists have to work with common wisdom while the primary aim of sociologists is to break away from common wisdom, which means that their scientific discourse is not often expressible in the social sphere.

As Elihu Katz suggests, there is a need for more studies on the way that these tools for investigation and objectivation are used in practice, and how journalists and sociologists give a voice to the "things" they observe. Such studies would perhaps bring better understanding of what makes a piece of information "relevant" in each group, and thus to specify their relationships with what is "hidden" (since investigative journalism and bringing social processes to light both obey the same logic of unearthing the truth).

\section{Conclusion}

The material that follows invites the reader to reconsider the history, as well as contemporary analyses, of the relationships between journalists and sociologists, with an emphasis on their common purpose of "giving an account of society". Rather than a reading in terms of two opposed professional spheres, these contributions prompt a dialectic and political approach to the competitive relations that link the two together. However, as we have seen, the field for analysis is wide open and other variables - social origins, dispositions, relationships with education or, to be more precise, the scholar's relationships with the world - may also account for the competitive familiarity that links these agents who are, finally, close in terms of habitus but who, for reasons that are partly awaiting definition, have chosen to invest their efforts in different activities. From this point of view, any analysis of relationships between journalists and sociologists must consider the changes that have occurred in the education system and how these have been used, mainly by the middle and upper classes. At the other end of the information process, it would be useful to investigate the nature of the different "social demands for intelligibility" in order to understand the contributions of the two disciplines to a "common core" of knowledge on society and thus of legitimate social representations. 


\section{BIBLIOGRAPHY}

Acrimed (Action critique médias), PLPL (Pour Lire Pas Lu), 2004, Petit manuel de l'observateur des médias (fascicule de 24 pages).

Arnault F., 1984, « Frédéric Le Play, de la métallurgie à la science sociale, Revue française de sociologie, XXV, pp. 437-457.

Balzac H. de, 1843, Monographie de la presse parisienne, Paris, A. Michel, 1981.

Bourdieu P., 1984, Homo academicus, Paris, Éd. de Minuit.

- 1994, «L'emprise du journalisme », Actes de la recherche en sciences sociales, 101-102, pp. 3-9.

- 1996a, Sur la télévision. Suivi de L'Emprise du journalisme, Paris, Éd. Liber-Raisons d'agir.

- 1996b, « La télévision peut-elle critiquer la télévision? Analyse d'un passage à l'antenne », Le Monde diplomatique, avril, p. 25.

Bourmeau S., 1988, « Journaliste et sociologue. Robert Ezra Park et la Presse », Politix, 3-4, pp. 50-61.

Brusini H., James F., 1982, Voir la vérité. Le journalisme de télévision, Paris, Presses universitaires de France.

Champagne P., 2001, « "Pouvoir des médias" et "pouvoir sur les médias”. Les raisons d'un débat récurrent ", pp. 195-213, in : Georgakakis D., Utard J.-M., dirs, Science des médias. Jalons pour une histoire politique, Paris, Éd. L'Harmattan.

Champagne P., Marchetti D., 1994, «L'information médicale sous contrainte. À propos du "scandale du sang contaminé" ", Actes de la recherche en sciences sociales, 101-102, pp. 40-62.

- 2002, « Censures visibles, censures invisibles », Les dossiers de l'audiovisuel, 106.

Chapoulie J.-M., 2001, La tradition sociologique de Chicago. 1892-1961, Paris, Éd. Le Seuil.

Charon J.-M., 1996, « Journalisme et sciences sociales. Proximités et malentendus », Politix, 36, pp. 16-32.

Coman M., 2003, Pour une anthropologie des médias, Grenoble, Presses universitaires de Grenoble. Contamin J.-G., 2001, Contribution à une sociologie des usages pluriels des formes de mobilization : l'exemple de la pétition en France, thèse de science politique, université Paris 1-Panthéon Sorbonne. Darras É., Philippe O., dirs, 2004, La science politique une et multiple, Paris, Éd. L'Harmattan.

Delporte Ch., 1999, Les journalistes en France (1880-1950). Naissance et construction d'une profession, Paris, Éd. Le Seuil.

Devillard V., Lafosse M.-F., Leteinturier C., Rieffel R., 2001, Les journalistes français à l'aube de l'an 2000. Profils et parcours, Paris, Éd. Panthéon-Assas.

Dor E., Valette B., 2002, Les vertus du mensonge. Information, déformation, manipulation, Paris, Sens \& Tonka.

Dunning E., 1996, «"Tout à fait, Éric...tout à fait!” Quand le sociologue sert de ballon de football aux médias. Souvenirs et réflexions préliminaires ", Politix, 36, pp. 5-15. 
Durkheim É, 1899, « Une révision de l'idée socialiste », Revue philosophique, 48, reproduit in: Textes , vol. 3, Paris, Éd. de Minuit, 1975, pp. 163-172.

Duval J., 2004, Critique de la raison journalistique. Les transformations de la presse économique en France, Paris, Éd. Le Seuil.

Elias N., 1969a, La dynamique de l'occident, Paris, Éd. Agora, 1990.

- 1969b, La civilization des mœurs, Paris, Éd. Agora, 1976.

- 1970, Qu'est-ce que la sociologie, Paris, Éd. Agora, 1993.

Ferenczi Th., 1992, L'invention du journalisme en France. Naissance de la presse moderne à la fin du XIXe siècle, Paris, Éd. Le Seuil.

François B., Neveu E., dirs, 1999, Espaces publics mosaïques. Acteurs, arènes et rhétoriques, des débats publics contemporains, Rennes, Presses universitaires de Rennes.

Gadhoum S., 2001, L'Écriture du social dans le « dictionnaire d'Antoine Furetière », thèse de Lettres, université de Provence.

Georgakakis D., Utard J.-M., dirs, 2001, Science des médias. Jalons pour une histoire politique, Paris, Éd. L'Harmattan.

Goulet V., 2003, « Pierre Bourdieu et la télévision », pp. 655-671, in : Mauger G., éd., Rencontres avec Pierre Bourdieu, Bellecombe-en-Bauge, Éd. du Croquant.

Grignon C., Passeron J.-Cl., 1989, Le savant et le populaire. Misérabilisme et populisme en sociologie et en littérature, Paris, Éd. Le Seuil.

Guillebaud J.-Cl., 1995, Écoutez voir !, Paris, Éd. Arléa.

Guisnel J., 2003, Libération, la biographie, Paris, Éd. La Découverte.

Halimi S., 1997, Les nouveaux chiens de garde, Paris, Éd. Liber-Raisons d'Agir.

Heilbron J., 2006, Naissance de la sociologie, Marseille, Éd. Agone.

Heilbron J., Lenoir R., Sapiro G., dirs, 2004, Pour une histoire des sciences sociales. Hommage à Pierre Bourdieu, Paris, Fayard.

Karady V., 1979, « Stratégies de réussite et modes de faire-valoir de la sociologie chez les durkheimiens ", Revue française de sociologie, XX, pp. 48-92.

Lacroix B., 1981, Durkheim et le politique, Paris-Montréal, Presses de la Fondation nationale des sciences politiques/Presses de l'université de Montréal.

Lagneau E., « Le style agencier et ses déclinaisons thématiques. L'exemple des journalistes de l'Agence France Presse », Réseaux, 11, pp. 58-100.

Lavoinne Y., 1992, « Le journaliste, l'histoire et l'historien. Les avatars d'une identité professionnelle (1935-1991) », Réseaux, 51, pp. 39-53.

Le Paige H., 1997, Une minute de silence. Crise de l'information, crise de la télévision, crise du service public, Bruxelles, Éd. Labor.

Le Play F., 1855, Les ouvriers européens. Étude sur les travaux, la vie domestique et la condition morale des populations ouvrières de l'Europe, précédées d'un exposé de la méthode d'observation, Paris, Imprimerie Impériale. 
Lettieri C., Saitta E., 2006, « L'identité journalistique à l'intersection des champs politique et intellectuel. Une comparaison France/Italie », pp. 61-84, in : Chupin I., Nollet J., dirs, Journalisme et dépendances, Paris, Éd. L'Harmattan.

Lévêque S., 2000, Les journalistes sociaux. Histoire et sociologie d'une spécialité journalistique, Rennes, Presses universitaires de Rennes.

Lyon-Caen J., 2002, « Le romancier, lecteur du social dans la France de la Monarchie de Juillet », Revue d'histoire du XIXe siècle, 24, pp. 15-32.

Marchetti D., 1997, Contribution à une sociologie des transformations du champ journalistique dans les années 80 et 90. À propos "d'événements sida » et du « scandale du sang contaminé ", thèse de sociologie, École des hautes études en sciences sociales.

- 2002, « Les sous-champs spécialisés du journalisme », Réseaux, vol. 20, 11, pp. 22-55.

- 2006, « La division du travail journalistique et ses effets sur le traitement de "l'événement". L'exemple du "scandale du sang contaminé" », pp. 141-160, in : Chupin I., Nollet J., dirs, Journalisme et dépendances, Paris, Éd. L’Harmattan.

Marchetti D., Ruellan D., 2001, Devenir journalistes. Sociologie de l'entrée dans le monde du travail, Paris, Éd. La Documentation française.

Martin M., 1997, Médias et journalistes de la république, Paris, O. Jacob.

Merllié D., 2004, «L'enquête autour de 1900. La non-participation des sociologues durkheimiens à une mode intellectuelle », Mil Neuf Cent. Revue d'histoire intellectuelle, 22, pp. 133-154.

Mucchielli L., 1995, « Heurs et malheurs du durkheimisme. Problèmes historiographiques, enjeux épistémologiques et pédagogiques d'une mémoire disciplinaire : la sociologie », Politix, 29, pp. 55-79.

Neveu É., 1999, « Médias, mouvements sociaux, espaces publics », Réseaux, vol. 17, 98.

- 2007, «L'université et la formation des journalistes », pp. 177-194, in : Pinto E., Pour une analyse critique des médias. Le débat public en danger, Broissieux, Éd. du Croquant.

Offerlé M., 1999, La profession politique XIX ${ }^{e}-X X^{\mathrm{e}}$ siècle, Paris, Belin.

Park E. R., 1944, Le journaliste et le sociologue, textes présentés et commentés par Muhlmann G., Plenel E., Paris, Éd. Le Seuil, 2008.

Phélippeau E., 2002, L'invention de l'homme politique moderne, Paris, Belin.

Piriou O., 1999, La sociologie des sociologues. Formation, identité, profession, Fontenay/Saint-Cloud, ENS Éd.

Ponet Ph., 2005, «La Guerre des mondes : de quelques rapports entre univers sociaux différenciés. Le cas des palmarès des hôpitaux », Politix, 72, pp. 125-154.

- 2007, « Les logiques d'une consécration journalistique. L'exemple des “50 meilleurs hôpitaux de France" ", Questions de communication, 11, pp. 91-110.

- 2009, Contribution à l'étude du processus de démocratization fonctionnelle. Autour des « affaires en responsabilité médicale », thèse de Science politique, université Paris 1, 2009.

Rémond E., dir., 1977, Journalisme et sciences sociales, Bordeaux-Talence, MSH Aquitaine.

Rieffel R., 1992, « Journalistes et intellectuels : une nouvelle configuration culturelle? ", Réseaux, 51, pp. 11-24. 
Roberts I., Garrigos R., 2006, La bonne soupe. Comment le « 13 heures » contamine l'info, Paris, Éd. Les Arènes.

Roussel V., 2002, Affaires de juges. Les magistrats dans les scandales politiques en France, Paris, Éd. La Découverte.

Roy A. du, 1992, Le serment de Théophraste. L'examen de conscience d'un journaliste, Paris, Flammarion.

Ruellan D., 1992, « Journalisme rencontres avec la recherche », Médiaspouvoirs, 28, pp. 23-29.

- 1993, Le professionnalisme du flou, Grenoble, Presses universitaires de Grenoble.

Ruffin F., 2003, Les petits soldats du journalisme, Paris, Éd. Les Arènes.

Schneidermann D., 1999, Du journalisme après Bourdieu, Paris, Fayard.

Sedel J. 2009, Les médias et la banlieue, Paris, INA/Éd. Le Bord de l'eau.

Shinn T., 2000, « Formes de division du travail scientifique et convergence intellectuelle. La recherche technico-instrumentale ", Revue française de sociologie, vol. 41, 3, pp. 447-473

Tavernier A., 2004, Paroles d'experts : les rhétoriques journalistiques de recours aux paroles extérieures dans Le Monde, Libération et le Figaro. Journalistes et sociologue, la construction d'un référentiel, thèse en sciences de l'information et de la communication, université Lille 3.

Virieu F.-H de., 1990, La médiacratie, Paris, Flammarion.

Wilensky H., 1964, « The professionalization of everyone ? ", American Journal of Sociology, vol. 70, 2, pp. 137-158.

Zola E., 1986, Carnets d'enquêtes. Une ethnographie inédite de la France, Paris, Plon, 1993.

\section{NOTES}

1. The difficulties inherent to analyses of the balance of power between two worlds that are both aspiring towards autonomy are also found in other combinations (such as relationships between journalists and doctors, doctors and "management", "management" and politicians, etc.), and therefore relate more generally to analyses of the "effects" of the ongoing social division of labour that has been accelerating since the early $20^{\text {th }}$ century (Ponet, 2009).

2. The expression "écrire le social" is borrowed from Gadhoum (2001).

3. Many journalists who aspire to act as intellectual references call on the social sciences in their writings and contributions - see Brusini, James (1982); De Virieu (1990); Ferenczi (1992); Du Roy (1992); Guillebaud (1995); Le Paige (1997); Schneidermann (1999); Dor, Valette (2002); Ruffin (2003); Roberts, Garrigos (2006) - while sociologists attempt to define what is "good journalism" in publications and public contributions that are very different to their academic output - see Bourdieu (1996a, 1996b); Halimi (1997); Rimbert (2006) or the brochure entitled Petit manuel de l'observateur des medias, published in 2004 by Acrimed and PLPL, on critiques of the media to which sociologists made contributions. For a different point of view, see also the account by Dunning (1996).

4. On the best-known polemic, between P. Bourdieu and D. Schneidermann, see Goulet (2003).

5. See for example the remarks of D. Schneidermann (1999: 33-52) on the "need to simplify to give an account of the complexité of the social sphere".

6. See J.-M. Charon (1996: 16-17) or D. Ruellan (1993: 7). See also the proceedings of the first symposium - as far as we know - organised on this question, with contributions from journalists, 
humanities researchers and others half-way between (Rémond, 1977). Finally, some journalists also publish academic works (Ferenczi, 1993).

7. Journalistes et sociologues: entre reconnaissance et méconnaissance, concurrence et collaboration, seminar during the $\mathrm{PhD}$ and young researchers' workshop on "Journalists and audiences", Paris, EHESS, 27-28 June 2006. On this subject, we would like to thank G. Bastin, A. Both, S. Capitant, A. Dauphin, S. Dimitrova, M. Endeweld, N. Harvey, F. Hein, L. Jeanpierre, J.-M. Leblanc, V. JeannePerrier and F. Perreira for their contributions, P. Champagne, S. Levêque, G. Mauger, D. Pasquier and Chr. Prochasson for having agreed to discuss the papers and qA. Borrell, S. Falguères, N. Hubé and Y. Patte for their contributions to the development of the seminar.

8. On this point, see the works of N. Elias (1969a, 1969b, 1970).

9. The publication of different writings of É. Zola under the title Carnets d'enquêtes. Une ethnographie inédite de la France (1986), in the Terre humaine collection is significant: while it reveals certain methods of observation that are close to those of ethnographers, the title of the work, the way the different texts are organised and the publishing house reveal how different disciplines could then make use of the relative lack of distinction between genres.

10. On this point, see Lyon-Caen (2002), who discusses the "observer of society" in the mid-19 century and identifies points in common between novels, social surveys and "panoramic literature".

11. See for example Georgakakis, Utard (2001: 9), or the preface and introduction to the publication directed by Darras, Philippe (2004: 7-40), which offer stimulating analyses of the combined processes of "professionalization" of political science as a discipline and the writing of its history.

12. On this point, see the informed work of Guisnel (2003).

13. Although these bibliographic references are by no means exhaustive, as regards sociology, see Heilbron (2006); Heilbron, Lenoir, Sapiro (2004); Karady (1979); Muchielli (1995). Regarding journalism, see Delporte (1999); Ferenzci (1992); Martin (1997); Ruellan (1993).

14. Since the "founding" article by H. L. Wilensky (1964), studies on how a group becomes a profession essentially focus on verifying that the group is endowed with the various statutory attributes considered as constituent elements of a profession. However, merely "noting" the presence of these different attributes in fact means contributing to the legitimation, through scientific resources, of what has been envisaged at a certain time by agents in the sector as a means of achieving autonomy. What is "noted" scientifically then tends to ratify the goals of certain battles, and is thus part of these disciplinary histories.

15. In the sense that they lay stress first of all "on the instotitional and disciplinary factors of the extension of scientific knowledge" (Shinn, $2000: 450$ ).

16. While sociology can now claim to be a profession on the basis of long-standing academic status, specific curricula, journals and learned societies, the professionalization of journalists is less well defined (Ruellan, 1993). Courses in journalism do not have a monopoly and training is frequently "on the job", as are changes in professional orientation with the development of specialised press publications.

17. On journalists, see, voir Neveu (1999); Marchetti (2002). On sociologists, see Piriou (1999).

18. Although the survey data need to be updated in order to make an assessment of the different possible distinguishing criteria in the academic world, see Bourdieu (1984: 64 et sq.), and also Piriou (1999).

19. For an analysis from this angle of the relationships between doctors and journalists, see Ponet (2005). It could even be added that these relationships also owe something to the local configurations in which they develop; for an analysis of relationships between journalists and magistrates that supports this view, see Roussel (2002:175-221).

20. On this aspect, see also Champagne (2001). 
21. This "strategy" should not be understood in the sense of the theory of the rational agents, but rather as a strategy without a strategist (on this point, see the texts by Karady, 1979) and Muchielli,1995), which would be akin to contributing to Durkheim's construction as a founding father

22. In this sense, it may be asserted that the social division of scientific labour plays a part in limiting its analyses of the processes involved in the division of labour .

23. Devillard et al. (2001); Marchetti, Ruellan (2001).

24. For an analysis of the links between thematic specialization and functional specialization among journalists, see Lagneau (2002).

25. Among the journalists most sensitive to the principle of internal legitimacy are those who have studied at journalism schools and who occupy positions in the national daily press. On this point, see Champagne, Marchetti (1994: 59).

26. Although, as noted by B. François et E. Neveu (1999), this decline seems to affect traditional disciplines (such as philosophy or the classics) more than the humanities (including psychology, economics, etc.).

27. On this point, it can be seen how recent demands for decompartmentalization and interdisciplinarity are as much in the interests of science as they are an oblique way of regaining a form of power by adjusting to an assumed social demand for overall expertise (in any case, indepth study is needed of those who launch interdisciplinary undertakings).

28. Acknowledging the importance of historical determinants in the structural organization of sociology, and of their effects in the current management of relationships with other social spheres, does not equate with deploring the "conservatism" (or, as current fashion would have it, "archaism") of the sociologists most closely linked with academia, in other words with retranslating structural processes into an underlying political logic. Insofar as a political variable needs to be introduced, this would be the increasing relegation of universities in the higher education sphere, which has accentuated the sense of decline - regardless here of whether it is justified or not - of the power of sociologists, and of intellectuals in general.

29. Much more generally, this question of the effects of the ongoing social division of labour on the balance of power between social groups is not specific to the links between journalists and sociologists, but relates to what N. Elias refers to as a process of "functional democratization" (Ponet, 2009).

30. The question of "political" retranslations should be considered together with the particular difficulties that seem to arise with the dissemination/popularization of sociological findings in the media, where there is always a risk - beyond the underlying motivations of exposure of the scientific sphere - of reducing them to political points of view. This again shows how the question of autonomy can be put to different uses.

31. See also Neveu (2007).

32. It is significant that while the call for papers for the seminar on journalists and sociologists (Journalistes et sociologues : entre reconnaissance et méconnaissance, concurrence et collaboration), 27-28 June 2006 referred explicitly to these questions, no papers were proposed on this topic.

33. From this point of view, the analyses by Contamin (2001: 311-357) are particularly stimulating. On more sporadic uses of the press by historians, see Lavoinne (1992).

34. On this particular form of class-based ethnocentrism, see Grignon, Passeron (1989:115).

35. É. Neveu (1999: 49) explains the desire to "break away from another analytical reduction: the Jacobin approach in which the only public sphere that is worthy of interest is the media scene comprising the Parisian daily papers and news magazines and generalist television news".

36. From this point of view, the fact that newspapers such as Le Monde or Libération have indexes in print and on CD-ROM, and the relatively recent deployment of the INA search engine, no doubt has an incidence on the over-representation of these media titles. 
37. For a summary of this debate, see G. Muhlmann's introduction to the writings of R. E. Park (2008).

\section{AUTHORS}

\section{VINCENT GOULET}

Centre de sociologie européenne

École des hautes études en sciences sociales, Paris

v.goulet.bx@voila.fr

\section{PHILIPPE PONET}

Centre de sociologie européenne

Université Paris 1-Panthéon Sorbonne

philippeponet@yahoo.fr 